\title{
Does Perception of Business Climate Differ Between Foreign and Local Investors? A Firm-level Study of Transition Economies in Eastern Europe and Central Asia
}

\author{
Olga Golubeva ${ }^{1}$ \\ ${ }^{1}$ Stockholm Business School, Stockholm University, Sweden \\ Correspondence: Olga Golubeva, Stockholm Business School, Stockholm University, 10691 Stockholm, Sweden.
}

Received: November 28, 2016

Accepted: January 14, 2016

Available online: January 23, 2017

doi:10.11114/aef.v4i2.2182

URL: http://dx.doi.org/10.11114/aef.v4i2.2182

\begin{abstract}
Difference between foreign and local investors in their respective assessments of business climate constraints has not yet been given much attention in research literature. Drawing on institutional theory and the concept of liability of foreignness (LoF), the study contributes towards filling this gap in the context of business climate variables faced by foreign firms operating in transition economies. The Mann-Whitney U Test is applied to firm-level data of 30 transition economies in Eastern Europe and Central Asia. We found that foreign investors experience less trouble with access to finance, tax rate and competition towards the informal sector compared with domestic firms. Conversely, such variables as courts, custom and trade regulations, inadequate workforce, and labor regulations disturbed foreign investors more than local companies. LoF appears as a balanced outcome of firm-specific advantages, possessed by foreign investors, and location and institutional advantages, utilized by the local companies. The results point towards important possible synergies in enhancing the business climate in transition economies by policy-makers, and to potential conflict between policy reforms accommodating the interests of foreign capital against those of domestic firms.
\end{abstract}

Keywords: business climate, foreign and local investors, liability of foreignness (LoF), transition economies, Business Environment and Enterprise Performance Survey (BEEPS)

\section{Introduction}

The term 'business climate' (alternatively known as 'investment climate' or 'business environment') is commonly employed by international policy-makers, researchers and business people to address the set of location-specific factors shaping the opportunities and incentives for firms to do business in a particular country and to attract Foreign Direct Investments (FDI). Countries' investment policy measures continue to be geared predominantly towards the improvement of the business climate. According to the World Investment Report, more than 80 per cent of investment policy measures during 2014 were intended to improve entry conditions and reduce restrictions for foreign capital (UNCTAD, 2015a).

FDI flows to emerging markets do play an important role, accounting for more than 40 per cent of external development finance received by these countries. UNCTAD estimates the contribution of Multinational Enterprises (MNEs) foreign affiliates to government budgets in emerging markets at approximately 730 billion USD annually. This represents, on average, some 23 per cent of total corporate contributions and 10 per cent of total government revenues (UNCTAD, 2015a). Hornerberger et al. (2011) suggested that many elements of the business climate can be reformed in the short term and at a comparatively low cost. Improving the business climate, therefore, offers an excellent opportunity for developing economies seeking to attract FDI. International evidence, on the other hand, suggests that many reform packages, implemented by emerging markets with expectations to create a friendly business climate for foreign investors, have not been successful in achieving the targeted outcome (Navaretti and Venables, 2004). One possible explanation of such a failure might be that governments and supporting international organizations lack an effective understanding of the differences that exist between foreign and local investors. If such differences do exist, then there is a need for additional support measures mitigating disturbances of the local business environment and assisting the attraction of FDI into emerging markets.

The term 'transition economies' appeared both in scientific literature and in common language to describe the state and 
development of emerging markets in Eastern Europe and Central Asia. FDI-related inflows to transition economies declined in 2014 by 52 per cent, reflecting raised geopolitical risks and regional sanctions in combination with falling oil prices. In contrast, inward FDI's stock in transition economies has grown to 725 billion USD by 2014 from a modest 1.6 billion USD in 1990 (OECD, 2015; UNCTAD, 2014). During this period, transition economies have been the fastest-growing hosts for FDI worldwide. The prospects for FDI in several transition countries are highly uncertain due to ongoing economic turbulence and potential 'spillovers' from geopolitical tensions. If transition economies are to continue to attract FDI, further work is needed to improve their business climates. Which variables of the investment climate should governments therefore prioritize when they develop packages of incentives in order to stimulate investors?

The differences between foreign and local investors in their assessment of business climate variables in transition economies do not appear as yet to have been given much attention in research literature. Drawing on applications of institutional theory and the concept of $\mathrm{LoF}$ to transition economies, this study contributes towards filling the gap. Specifically, the objective of this paper is to analyze whether the perceptions of selected variables of business climate differ between foreign and local investors. By doing this, we attempt to expand the domain of LoF research in the context of business climate variables faced by foreign firms operating in transition economies. We compare foreign and local firms as LoF is inherently a relative concept, and its existence and degree of operation can only be assessed relative to host-country companies.

A firm-level approach has been adopted to study transition economies in Eastern Europe and Central Asia. Furthermore, the article is limited to analysis of perception-based empirical data acquired through a survey, a method that has recently attracted the attention of several researchers (Hallward-Driemeier and Aterido, 2009; Hallward-Driemeier and Pritchett, 2011).

The findings of the article offer some guidance to the host transition countries and international development agencies concerning those business climate variables which require additional support to accommodate the needs of foreign investors. If the constraints of the business climate exert an equal influence on foreign and local investors then the elaboration of similar incentive policies by the host governments are justified for all types of investors.

The remainder of the paper is structured as follows: firstly, we review the theoretical concepts relevant to the purpose of the study. Secondly, we introduce the methodology of investigation, define the major variables, and formulate null and alternative hypotheses regarding the perception of business climate in transition economies by foreign and local investors. Thirdly, we present the statistical analysis of the empirical data and capitalize the outcome of the study to formulate a future research agenda.

\section{Foreign and Local Investors in Transition Economies}

\subsection{International Expansion and LoF}

Leading scholars starting from Hymer (1960/1976) have argued that firms operating abroad face considerable challenges due to unfamiliar local norms and values, different economic, political, and legal systems, lack of experience in foreign markets and the geographic distances between the home and foreign host countries. Such disadvantages experienced by foreign firms compared to local companies have been termed 'liability of foreignness' (LoF). Zaheer (1995) pointed to four sources of LoF: (1) costs related to spatial distance, for example, transportation expenditures and coordination of business activities; (2) firm-specific costs arising from the company's unfamiliarity with the environment of the host country; (3) costs arising from the specific environment of the foreign country, such as administrative barriers or economic nationalism; and (4) costs caused by regulations in the home country, such as the restrictions on high-technology exports to certain countries or embargos on trade. International business research has argued that foreign firms must overcome LoF and thus need to engage in isomorphism to gain legitimacy in order to survive in a host business environment.

Numerous studies have examined LoF and, in many cases, have confirmed that LoF-based competitive disadvantage exists and that it results in foreign affiliates underperforming when compared to local firms (Miller and Eden, 2006; Elango, 2009). Commonly seen as a constant detriment to a firm's success in foreign expansion, LoF may ease to some extent as the firm gains experience in international operations (Contractor, et al. 2003; Lu and Beamish, 2004). The firm incurs, therefore, the highest LoF costs at the beginning of its international expansion, gradually reducing them over time due to economies of scale and scope, exploiting arbitrage opportunities and market imperfections, and enhancing the company's knowledge base and competitiveness.

Due to the importance of business networks in the modern economy, Johanson and Vahlne (2009) suggested that a lack of institutional knowledge related to psychic distance constitutes LoF while a lack of market-specific business knowledge creates the liability of outsidership. Companies are expected, therefore, to achieve internalization based on their relationships with the countries where they have valuable marketing network positions. The network approach 
views FDI as the construction of a link between a domestic network and a foreign network, rather than a profit-seeking motive aimed at extracting economic rent from a foreign market by exploiting its own strategic assets.

The classical economic model, on the other hand, assumes that MNEs systemically engage in a cost-benefit analysis of different internationalization strategies and then select the optimal one. A company's international expansion is intrinsically profit-driven. The importance of the profitability factor in the internalization process has been emphasized by several scholars (Kinda, 2010; Mottaleb and Kalirajan, 2010; Nnadozie and Njuguna, 2011; Golubeva, 2016). The degree to which a firm finds success in global expansion, however, is usually regarded as the result of a trade-off between its specific advantage (Hymer, 1960/1976) and the generic challenges of expanding overseas. According to the conventional, resource-based argument, firms leverage their unique home strengths in new markets through trade, licensing and FDI, but face constraints such as physical distance, cultural differences and LoF. MNEs' specific advantages form the basis of global expansion because they are superior in absolute or in relative terms (Yip, 2003).

The conventional wisdom of the LoF was challenged by some scholars who argue that LoF may not exist, and that foreignness may be either an asset or a liability depending on the circumstances (Kronborg and Thomsen, 2009; Nachum, 2010). If we look at the internalization process and its players from 'the other side of the fence', locally owned firms operating in their home country may also suffer certain disadvantages due to the arrival of foreign competitors in their home markets. Perez-Batres and Eden (2008) were among the first to define the concept of liability of localness (LoL). LoL is the added cost faced by local firms on account of changes in the regulatory environment within the host country favoring foreign firms over local firms. The empirical result of Jiang and Stening (2013) suggests that for local Chinese firms incur a LoL, and the extent of the negative impact of such liability on local firm performance is largely dependent on the relative strength of the various advantages that the local and foreign firms possess.

Although LoF is a well-developed concept and has been investigated in many theoretical and empirical studies, it still remains largely a black box (Eden and Miller, 2001). Scholars, therefore, have called for the development of a more calibrated analysis of LoF and its application in different institutional contexts (Insch and Miller, 2005). Yildiz and Fey (2012) suggest that a more finely-tuned approach should look at how the extent of LoF would vary depending on the institutional setting within which firms operate. According to scholars, MNEs may face lower pressures for conforming to local rules in transition economies where institutional frameworks are not well developed.

\subsection{Investment Environment of Transition Economies}

Institutional theory has widely been used as a lens for studying the investment environment of transition economies (Bevan, et al. 2004; Estrin, et al. 2009). We apply the term 'Northian institutional theory' to reflect the theories of institutions that are, largely, but not solely, grounded in economics following North (1990). In the Northian view, formal and informal institutions generate the "rules of the game" which shape the national economics of the countries concerned. These rules include requirements, constraints, enforcement mechanisms, and incentive structures which together provide an exchange environment (Dunning and Lundan, 2008; Meyer, et al. 2009). Northian institutional theory generally takes the view that firms will adapt to the institutional environment since institutional rules constrain or motivate certain actions by affecting their value or their cost.

Emergent post-socialist markets in Eastern Europe and Central Asia, often labeled as transition economies, are a 'dual system' in which many elements of centrally-planned and market economies exist side by side (Golubeva, 2001). Communist central planning institutions required firms to fulfill government plans and production quotas, to attain full employment, to execute the decisions of government agencies and to maintain relationships with bureaucrats (Zhou, et al. 2006; Shinkle and Kriauciunas, 2012). As a consequence, local firms were not focused on profitability and not exposed to real competition; companies had almost no risk of failure, and they did not decide the future strategy (Zhou, et al. 2006). In contrast, institutions in market-oriented environments are characterized by the possibility of a company to choose its strategy, but also by the allowance of a firm to fail and go into bankruptcy (North, 1990; Makhija, 2003). In this environment, firms' strategic choices directly relate to outcomes, performance, and survival based upon the support of market-based, arm-length transactions through incentive structures and enforcement mechanisms (Peng, 2003; Dunning and Lundan, 2008).

The most notable change in transition economies is the gradual dismantling of the central planning regimes, replaced by more market-based transactions to facilitate economic exchange. Such transitions occur in two phases. Firstly, the government weakens the planning system for the economy as the new market system is being developed; and secondly, more transparent rules are introduced (Peng, 2003). Thus, during the transition process, the institutional infrastructure for market competition remains underdeveloped and leaves significant institutional voids. These shortages lead to dysfunctional competition, characterized by problematic enforcement of legislation and regulations, slow societal changes in norms, and conflicting rules co-existing during institutional transitions (Huang, 2008). It is not clear, however, how this ambiguity of institutional environment of transition economies impacts on foreign and local investors. 
The empirical results of Shinkle and Kriauciunas (2012) suggested that the founding institutional environments of centrally-planned economies temper adaptation to currently emerging market-economy institutional environments. As a result, foreign firms that possess imprinted, market-founded practices and investment decision routines will have certain competitive advantages in transition economies which might help them eventually to overcome their LoF. However, a parallel theoretical view argues that firms will be shaped by their founding centrally-planned institutional environment (Kogut and Zander, 2000). This view predicts that foreign firms will be constrained in their ability to adapt to the 'rules of the game' in transition economies due to imprinted structures and practices of the business environment inherited from the centrally-planned economies and of which foreign companies are ignorant. Consequently, foreign firms might experience even higher LoF in transition economies than in other institutional environments.

Depending on different theoretical inputs from 'Northian institutional theory', contradictory argumentation exists supporting both higher and lower LoF that are experienced by foreign companies in transition economies. Due to the uncertainty and the unpredictability of developments in transition economies, both foreign and local firms may have equal challenges to survive in this institutional environment.

Furthermore, foreign firms are afforded relatively set comprehensive and symmetrical information when investing in developed economies (Xu, et al. 2010). In contrast, in emerging economies, where the institutions are underdeveloped, the business environment is fragile and the legal protection is insufficient, there is a high level of informational shortcomings and asymmetry (Dierks, et al. 2013; Williams, et al. 2014). Such information deprivation might result in a greater LoF for foreign firms in transition economies (Wei and Clegg, 2014).

Scholars have long realized that government plays a critical role in business operations and firm performance in developed economies by formulating rules, laws, and policies for the business environment (Hillman, et al. 2004). The impact of the government, however, might be even stronger in transition economies, according to how that government determines the pace of institutional changes and develops the rules of behavior in the transition context (Yiu, et al. 2014). Additionally, due to the fact that institutions are still under development, the government eventually plays a more significant role in transition economies than it does in mature markets (Walsh, et al. 2009). For example, a specific transition economy may have weaker rules to ensure effective and fair competitions, and its laws govern contracts and protect property rights are lacking or inadequately enforced. To fill in such institutional voids, government sometimes directly conducts business operations (Oliver and Holzinger, 2008).

Although one can still observe evidence of discriminatory policies applied by host countries (Cuervo-Cazurra, et al. 2007), it is more common to observe a fierce competition among transition economies for attracting more foreign investors by offering them generous fiscal and financial incentive packages. The case that MNE receive equal or even more favorable treatment by governments in the context of transforming economies has been emphasized by several scholars (Yildiz and Fey, 2012; Obradovića, et al. 2012). Attracting FDI can be viewed, therefore, as one of the ways by which transitional economies accomplish transmission tasks. In order to attract foreign investors to transition economies, governments should create a favorable business climate, which in turn requires a number of economic, institutional, political and other reforms (Hornerberger, et al. 2011; Obradovića, et al. 2012).

\subsection{The Concept of Business Climate}

The classical economic model assumes that foreign investors prefer to invest in countries where companies can operate their businesses at a low cost and produce commodities and services with competitive market prices (Kinda, 2010; Mottaleb and Kalirajan, 2010; Nnadozie and Njuguna, 2011; Golubeva, 2016). Moreover, business environment and rules and regulations relating to investment might also affect the cost of doing business in a country. Some scholars have argued that the profit-related incentives for investors do not generally work unless they are appropriately combined with other incentives to improve the general investment climate (Athukorala, 2009). A similar logic is articulated in LoF literature (Sethi and Guisinger, 2002) where it is argued that a foreign firm operating in a foreign country with the inherent disadvantages relative to local firms will take a proactive role to adjust to the local business environment.

But what is the business climate? The business climate is often defined as a complex of political, legal, institutional and regulatory conditions affecting the business activities (Donor Committee for Enterprise Development, 2008). A few researchers have suggested defining investment climate through the perceptions of business owners (Motoyama and Hui, 2015) or, in particular, those of foreign investors (Golubeva, 2015). Motoyama and Hui (2015) offer a new definition of business climate as "a case-specific condition and a subjective perception by individuals" (p. 264). The authors also argue that the business climate is better conceived and measured at the individual firm level.

Featuring many aspects, the business environment is probably a multidimensional phenomenon that has to be divided into components, in order to analyze their individual impact on the inflow of FDI. Various macroeconomic, political, infrastructures, social and cultural variables have been included in the analysis of the business climate. Appendix A 
summarizes selected contributions from main-stream research papers on the determinants of FDI and business climate.

The most frequently discussed factors in research literature include economic and political stability, regulatory frameworks and quality institutions, infrastructure, the educational system, trade and tax system reform, labor market characteristics and corruption. However, there are certain inconsistencies in conclusions between the studies, and the empirical evidence remains often ambiguous. Durlauf et al. (2008), for example, suggest that previous findings on the direct importance of institutions on FDI are often exaggerated. The empirical results of the study by Goswami and Haider (2014) refute the conventional notion that government failure is an important factor contributing to poor FDI inflow. Rather, cultural conflict and the attitude of the partner country towards the host country are found to be mostly responsible for deterring FDI inflow. Blonigen and Piger (2011) also found no robust evidence that government policy variables controlled by the host country have an effect on FDI. Many studies emphasize the open-ended character of this research field and suggest more efforts need to be focused on the systematization and testing of business climate variables to reflect their priority for investment decision-making.

It can also be concluded that the authors have primarily focused on the endogenous factors of the business climate, trying to point out the importance of reforms to be implemented in order to attract foreign investors (Birsan and Buiga, 2009). The move towards FDI-friendly regulations in the host transition countries provides a direct challenge to Hymer's (1960/1976) notion of the "stigma of being foreign" (p. 35), which can be identified as a major cause of the LOF. Tan and Meyer (2011), however, highlighted the outsidership of foreign investors in the local environment, especially for markets with weak institutions. This topic is particularly relevant for transition economies because the underlying institutional mechanisms of the host countries are typically underdeveloped.

\section{Data Source and Methodology}

\subsection{BEEPS as a Data Source for Analysis}

The article analyzes the empirical data from a "Business Environment and Enterprise Performance Survey" (BEEPS) ${ }^{1}$ that was jointly performed by the World Bank and EBRD during 2012-2014. BEEPS included 15,883 enterprises in 30 transition countries of Eastern Europe and Central Asia. The survey summarized the feedbacks from firm managers about selected variables of the business environment in these transition countries. Both the subjective data on the perceptions of managers and the objective data on various business climate indicators were recorded. The core questions were answered by managers or owners of the firms through face-to-face interviews followed by complementary accounting data being provided by the participating companies. A review of the literature, drawing primarily on the World Bank \& EBRD's Enterprise Survey data is provided by Xu (2010).

There have been extensive discussions about the possible weaknesses of subjective, perception-based surveys compared with objective, quantitative data. Exploring such concerns, Gelb et al. (2007) concluded that, while perceptions of business climate constraints may not always correspond fully to 'objective' reality, firms do not complain indiscriminately; response patterns correlate reasonably well with several other country-level indicators related to the business climate. Hallward-Driemeier and Aterido (2009) also demonstrated that qualitative rankings correlate well with quantitative measures of the business environment, according to both quantitative measures from within the survey and from external sources. Furthermore, Bertrand and Mullainathan (2001) suggested that subjective variables are especially useful for explaining differences in behavior across individuals or groups. According to researchers, few findings cast serious doubts on attempts to use subjective data as dependent variables, because the measurement error appears to correlate with a large set of characteristics and behaviors. However, when the data is used to compare two groups - like local and foreign investors in our case - this concern is somewhat mitigated. Finally, a subjective managerial assessment approach has been widely used in research studies focused on emerging markets. Devonshire-Ellis and Zhang (2011), for example, noted that accounts in China have consistently been shown to be incorrectly prepared for reasons ranging from incompetence to fraud. Therefore, subjective measures of firm performance might eventually be more motivated for studying transition economies than developed countries.

\section{2 'Transition Economies' Included into Analysis}

Although the term 'transition economies' usually covers the countries of Central and Eastern Europe and the former Soviet Union, it is sometimes used in a wider context. There are countries in Asia, emerging from a socialist-type command economy towards a market-based economy. (For example, Mongolia is included by the World Bank in some studies of transition economies.) Additionally, transition trajectories have varied considerably with respect to speed and the content of the reforms. Eight transition countries joined the EU in 2004 (Czech Republic, Estonia, Hungary, Latvia, Lithuania, Poland, Slovakia and Slovenia) and two more transition economies accessed the EU in 2007 (Romania and Bulgaria).

The EBRD-World Bank BEEPS applies a broader definition of transition economies and includes 30 countries in the survey: Albania, Armenia, Azerbaijan, Belarus, Bosnia and Herzegovina, Bulgaria, Croatia, Czech Republic, Estonia, 
Former Yugoslav Republic of Macedonia, Georgia, Hungary, Kazakhstan, Kosovo, Kyrgyz Republic, Latvia, Lithuania, Moldova, Mongolia, Montenegro, Poland, Romania, Russia, Serbia, Slovak Republic, Slovenia, Tajikistan, Turkey, Ukraine, and Uzbekistan.

In accordance with the analytical purpose of this paper, we do not propose to amend the selection of countries for reasons of geographic proximity and certain similarities in transformational challenges. For example, the literature suggests that transition economies are more vulnerable to external shocks and crises than advanced countries (Reinhart and Rogoff, 2009), a point which was clearly revealed during the Global Financial Crisis of 2007-2009 (Shostya, 2014). Selected macroeconomic indicators and indexes for these 30 countries are summarized in Appendix B.

\subsection{Definition of Variables and Hypothesis Formulation}

Consistent with previous research, the following 16 parameters of business climate were selected for the study: access to finance; access to land; business licensing and permits; corruption; courts; crime, theft and disorder; customs and trade regulations; electricity; inadequately-educated workforce; labor regulations; political instability; practices of competitors in the informal sector; tax administration; tax rates; telecommunication and transport. The variables have been chosen for their economic relevance and also in accordance with the number of non-missing values.

For the study, the foreign-owned companies were separated from the firms owned by local investors. FDI is defined as an investment involving a long-term and lasting control by a foreign direct investor of 10 per cent or more of the foreign enterprise resident within a different economy (UNCTAD, 2015b). Utilising the standard FDI definition, the same criteria were applied in the study to separate the foreign investors from the domestic owners. Ownership of less than $10 \%$ of a company's shares was considered a portfolio investment and therefore disregarded in our analysis.

Managers chose one of the alternatives that most adequately described their perception of a selected factor of the business climate as follows: $0=$ no obstacle, $1=$ minor obstacle, $2=$ moderate obstacle, 3 = major obstacle, $4=$ very severe obstacle. A lower ordinal score, therefore, reflects a more positive perception of this particular variable.

The nonparametric Mann-Whitney $\mathrm{U}$ test ${ }^{2}$ has been applied to determine whether or not, the perception towards variables of the business climate differs between two independent groups of investors ("local" and "foreign") when the selected variables are measured on the provided ordinal scale. The research design of the study complies with the assumptions required for the application of the Mann-Whitney $U$ test. A significance level of 0.05 has been applied.

The null hypothesis $\left(H_{0}\right)$ assumes that there is no difference between the respective assessments of selected variables of the business climate by the foreign $\left(\mu_{\text {foreign }}\right)$ and local investors $\left(\mu_{\text {local }}\right)$. The alternate hypothesis $\left(H_{1}\right)$ assumes that there is a difference between the respective assessments of selected variables of the business climate by the foreign $\left(\mu_{\text {forelgn }}\right)$ and local investors $\left(\mu_{\text {local }}\right)$.

\section{$H_{0}: \mu_{\text {forelgn }}=\mu_{\text {local }} \quad H_{1}: \mu_{\text {forelgn }} \neq \mu_{\text {local }}$ \\ 4. Empirical Results, Analysis and Future Research Agenda}

\subsection{Empirical Results}

The mean rank indicates whether foreign or domestic investors have the higher assessment of a particular variable of business climate; it should be recalled that the group with the lowest mean rank has the more favorable assessment. Table 1 provides descriptive statistics and summarizes results of the Mann-Whitney U test. 
Table 1. Descriptive statistics and results of a Mann-Whitney $U$ test for selected variables of business climate

\begin{tabular}{|c|c|c|c|c|c|c|c|}
\hline Variables of business climate & $\begin{array}{l}\text { Local / } \\
\text { foreign }\end{array}$ & $\mathrm{N}$ & Mean & $\begin{array}{l}\text { Std. } \\
\text { deviation }\end{array}$ & Variance & $\begin{array}{l}\text { Mean } \\
\text { rank }\end{array}$ & $\begin{array}{l}\text { Mann-Whitney U } \\
\text { Asymp.Sig. } \\
\text { (2-tailed) }\end{array}$ \\
\hline \multirow[t]{2}{*}{ Access_finance } & Local & 14380 & 1.1555 & 1.29394 & 1.674 & 7755.25 & 0.000 \\
\hline & Foreign & 1032 & 0,9312 & 1.18760 & 1.410 & 7027.27 & \\
\hline \multirow[t]{2}{*}{ Access_land } & Local & 13756 & 0.6210 & 1.14686 & 1.315 & 7390.50 & 0.254 \\
\hline & Foreign & 1007 & 0.5541 & 1.06115 & 1.126 & 7265.93 & \\
\hline \multirow[t]{2}{*}{ Business_licence_permits } & Local & 13921 & 0.5750 & 1.04853 & 1.099 & 7468.46 & 0.891 \\
\hline & Foreign & 1017 & 0.5664 & 1.01745 & 1.035 & 7483.70 & \\
\hline \multirow[t]{2}{*}{ Corruption } & Local & 14061 & 1.1732 & 1.39506 & 1.946 & 7548.03 & 0.281 \\
\hline & Foreign & 1015 & 1.1192 & 1.36762 & 1.870 & 7406.45 & \\
\hline \multirow[t]{2}{*}{ Courts } & Local & 13977 & 0.4418 & 0.94538 & 0.894 & 7469.79 & 0.002 \\
\hline & Foreign & 1005 & 0.5015 & 0.94850 & 0.900 & 7793.42 & \\
\hline \multirow[t]{2}{*}{ Crime } & Local & 14415 & 0.6456 & 1.07883 & 1.164 & 7730.74 & 0.402 \\
\hline & Foreign & 1032 & 0.6163 & 1.06257 & 1.129 & 7629.91 & \\
\hline \multirow[t]{2}{*}{ Custom_trade_regulations } & Local & 13208 & 0.5689 & 1.04836 & 1.099 & 7045.59 & 0.000 \\
\hline & Foreign & 1011 & 0.7933 & 1.11239 & 1.237 & 7951.50 & \\
\hline \multirow[t]{2}{*}{ Electricity } & Local & 14575 & 0.9967 & 1.37400 & 1.888 & 7801.99 & 0.452 \\
\hline & Foreign & 1041 & 1.0567 & 1.44703 & 2.094 & 7899.62 & \\
\hline \multirow[t]{2}{*}{ Inadequate_workforce } & Local & 14470 & 0.9793 & 1.29164 & 1.668 & 7724.33 & 0.006 \\
\hline & Foreign & 1025 & 1.0693 & 1.27172 & 1.617 & 8082.08 & \\
\hline \multirow[t]{2}{*}{ Labour_regulations } & Local & 14520 & 0.5567 & 0.95952 & 0.921 & 7756.76 & 0.001 \\
\hline & Foreign & 1043 & 0.6366 & 0.97929 & 0.959 & 8133.33 & \\
\hline \multirow[t]{2}{*}{ Political_instability } & Local & 14283 & 1.2884 & 1.40406 & 1.971 & 7643.63 & 0.156 \\
\hline & Foreign & 1029 & 1.3440 & 1.40046 & 1.961 & 7835.14 & \\
\hline \multirow[t]{2}{*}{ Practices_informal_sector } & Local & 13534 & 1.1147 & 1.32135 & 1.746 & 7295.78 & 0.000 \\
\hline & Foreign & 980 & 0.9316 & 1.25519 & 1.576 & 6728.88 & \\
\hline \multirow[t]{2}{*}{ Tax_administration } & Local & 14474 & 1.0225 & 1.22984 & 1.513 & 7763.08 & 0.365 \\
\hline & Foreign & 1035 & 0.9749 & 1.18393 & 1,402 & 7642.05 & \\
\hline \multirow[t]{2}{*}{ Tax_rate } & Local & 14520 & 1.8620 & 1.38993 & 1.932 & 7836.32 & 0.000 \\
\hline & Foreign & 1035 & 1.5845 & 1.30590 & 1.705 & 6959.90 & \\
\hline \multirow[t]{2}{*}{ Telecommunication } & Local & 14549 & 0.7508 & 1.21612 & 1.479 & 7780.54 & 0.111 \\
\hline & Foreign & 1037 & 0.8120 & 1.24907 & 1.560 & 7975.35 & \\
\hline \multirow[t]{2}{*}{ Transport } & Local & 14405 & 0.7988 & 1.17359 & 1.377 & 7711.72 & 0.493 \\
\hline & Foreign & 1029 & 0.8474 & 1.23071 & 1.515 & 7798.42 & \\
\hline
\end{tabular}

For the first group of variables, namely access to land; business licensing and permits; corruption; crime, theft and disorder; electricity; political instability; tax administration; telecommunication and transport, there are no statistically significant differences between foreign and domestic investors. Therefore, there are grounds to suggest that, for these factors of business climate, MNEs managed well in leveraging their competitive advantages against institutional pressures of transition economies' environment and LoF probably does not exist.

Based upon the $p$-values, the null hypothesis can be rejected for the second group of variables of business climate: access to finance, courts, custom and trade regulations, inadequate workforce, labor regulations, practices of competitors in the informal sector and tax rate. For these variables, there is statistical evidence that there are significant differences in perceptions between foreign investors and local owners.

Taking into account the value of the mean ranks, foreign investors seem to experience less trouble with access to finance, tax rate and competition in the informal sector compared with domestic firms. For these variables, a competitive advantage of foreign firms over their local counterparts is statistically supported, implying the existence of LoL as defined by Perez-Batres and Eden (2008). This result is consistent with the fact that many transition countries have liberalized their regulations and have begun to adopt FDI- friendly policies. In these contexts, a firm's foreignness might be an advantage in gaining eligibility for generous investment incentives offered by host transition economy governments.

Conversely, such variables as courts, custom and trade regulations, inadequate workforce, and labor regulations troubled foreign investors more than domestic companies. For these variables of business climate, MNE operating in transition economies seem to experience a negatively discriminatory treatment from host country governments, which indicates the existence of LoF. Differences in the assessment of variables of business climate between foreign and local investors that have proved to be significant through the application of a Mann-Whitney $U$ test are summarized at Figure 1. 


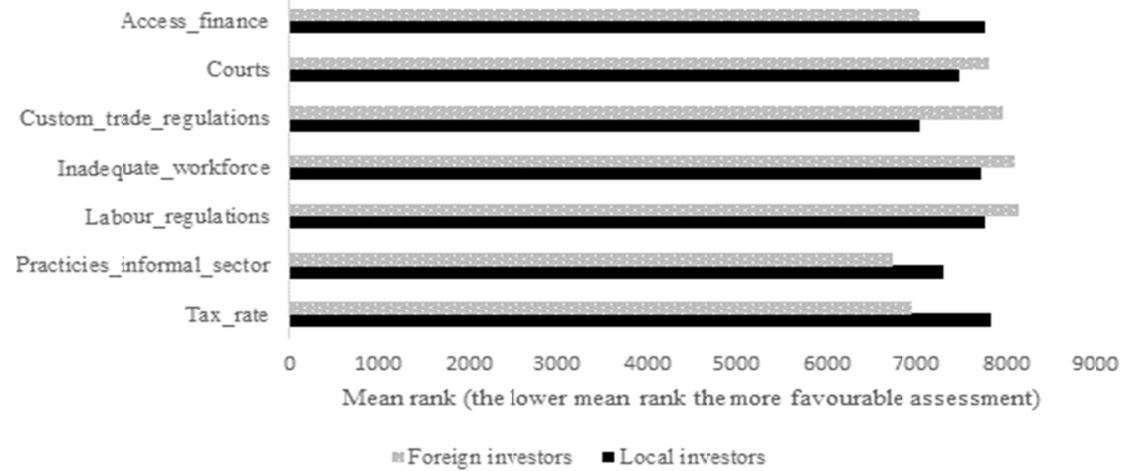

Figure 1. Differences in assessment of variables of business climate between foreign and local investors that proved to be significant through a Mann-Whitne U test

\subsection{Analysis}

The results of our empirical cross-country analysis suggest a certain pattern of assessments of business climate in transition economies by foreign investors compared to local owners.

We have identified three variables of business climate where foreign investors have expressed less concern in the evaluation of constrains than local firms. There are grounds, therefore, to suggest that MNE were able to leverage on their international experience and reputation, economies of scale and scope, etc. to balance the additional costs arising from LoF.

Constraints related to finance are broadly recognized by academicians as being essential for business climate and the attraction of FDI investors (Phillips, 2006; Kinda, 2010). Access to finance in our study seems to be a less important constraint for foreign investors, eventually due to the financial support which can be provided by the parent company. Although this factor does not constitute a severe problem for foreign owners, fostering local business, however, can demand an easing of access to finance. Empirical evidence from our study provides some support for the introduction of new initiatives by local governments that, for example, will enhance building partnerships between domestic firms and financially strong MNEs. Additionally, the use of government development funds as seed capital, building and supporting go-to-market channels for investment projects, and expanding the use of investment guarantees and risk insurance facilities, may be considered.

Based on data for 85 countries, Djankov et al. (2009) have found that corporate tax rates correlate negatively with aggregate investment and FDI. According to our study, the tax rate is perceived by foreign-owned companies as a less important constraint than it is by domestic firms. There is no evidence in our study suggesting that positive assessment of tax rates is influenced by tax-optimization policies pursued by some MNE; however, there are grounds to be cautious. The 'World Investment Report' (UNCTAD, 2015a) highlighted the importance of fostering good tax behavior in conjunction with foreign investments. There is an obvious need for researchers to invest more efforts in analyzing cross-border corporate tax avoidance schemes played by foreign investors, and for policy-makers to continue work on eliminating such activities.

The main-stream research suggests that policies that enhance the informal sector are likely to have negative effects on investors. Recent evidence suggests that the informal sector tends to attract low-productivity workers (La Porta and Shleifer, 2008). In our study, competitors in the informal sector affected foreign investors less than they did the domestic firms. An intuitive explanation might be that foreign companies have more opportunities to avoid the informal sector, especially if this sector comprises mainly of low-productivity work forces and produce local or illegal trade brands. Osland and Osland (2005) suggested that MNE operating in Central America have a good reputation and that their human resource policies attract highly-qualified employees. In addition, the marketing research contributed with few studies showing that consumers in transition economies often prefer foreign brands to local ones (Hao, et al. 2007). MNE operating in transition economies, therefore, has good possibilities of minimizing their exposure to informal sector or simply avoid it.

All three variables of business climate - availability of finance, corporate tax rate and ability to avoid competition with informal sector - are mostly related to firm-specific advantages (FSA), which have constituted the building blocks of foreign direct investment research since Hymer (1960/1976). An argument that superior FSAs of MNE mitigate LoF and enhance firms' competitiveness seems to be valid also for transition economies.

The perception of courts, custom and trade regulations, inadequately educated workforce, and labor regulations, on the other hand, all appeared to indicate more constraints for foreign-owned companies than for the domestic ones. 
Courts are an important institution for property rights protection. Using the World Bank Investment Climate data, Long (2010) confirmed that a better local court system is associated with a higher investment rate. Laeven and Woodruff (2008) discovered that firm size is related to the perception of the local legal and court systems. Based upon the results of our study, we can add that ownership also matters. In our study, constraints relating to courts were less favorably assessed by foreign investors than by local firms. A good court system would sustain firms' expectations that their contractual rights would be honored in the face of contract breaches, allowing them to commit necessary investments and to expand without worrying about contract reneging. For foreign investors, the demand for arms-length enforcement becomes even more vital. The advice to governments of transition economies, based upon empirical results of our study, is to continue work on overcoming imperfections in their domestic court systems.

Openness, including custom and trade regulations, is another important factor for attracting foreign capital to emerging markets (Navaretti and Venables, 2004) and transition economies (Bevan, et al. 2004). Custom and trade regulations appeared to have worse assessments from foreign investors in our study. Public authorities should probably increase their efforts to navigate foreign companies through local customs and trade rules and regulations. The scope of such work can range from information distribution to practical assistance in making contact with relevant state servants.

Glaeser et al. (2004) found that human capital is a more basic source of growth than are institutions. Availability of qualified managers affects the economy, and lack of human capital can adversely affect the business climate. Inadequately educated workforce, in our study, appeared to be a more severe constraint for foreign investors compared with local companies. In order to address the issue, more work is required in raising educational standards in the host countries. Local governments should stimulate more active contributions towards professional education by MNE in the latter's operational countries. Incentive packages should not be limited to investments in production facilities and profit repatriation, but should include the development of human resources and knowledge transfer.

Gelb et al. (2007), looking at labor regulations, argue that such policies have become serious determinants of the business climate. In our study, labor regulations were reported as a more serious concern for foreign investors than for the domestic firms. It is recommended that local governments of transition economies should provide more information for foreign investors regarding labor regulations and assist in developing contacts between MNE and local trade unions.

All four variables of business climate that appeared to be more severe constraints for foreign firms compared to local ones - courts; custom and trade regulations; labor regulations and inadequately educated workforce - are mostly related to institutional environment and companies' location competitive advantages. It seems that foreign companies experience disadvantages or LoF compared to local firms when variables of business climate related to institutional environment are addressed.

The empirical evidence of our study suggests, therefore, that local firms in transition economies might rely more on institutional-based competitive advantages whereas foreign firms might need to utilize FSA to overcome LoF. This conclusion is supported by previous studies, although in different research contexts (Hermelo and Vassolo, 2010; Jiang and Stening, 2013).

We found no statistically significant difference between foreign and domestic investors for the following variables: access to land; business licensing and permits; corruption; crime, theft and disorder; electricity; political instability; tax administration; telecommunication; transport. The results point to important potential synergies in enhancing the business climates of transition economies. If the constraints of the business climate are assessed similarly by foreign and local investors, then the elaboration of similar governance policies and incentive packages by the host governments are justified.

\subsection{Future Research Agenda}

While significant reforms of business climates in transition economies have been carried out, there is an urgent need for forward-looking research reflecting the dynamics of the process. Certain aspects of business climate were important for investors during the earlier stages of transformation, but there may be a shift in perception when reforms advance. While transition moves forward, the extent of the market-supporting formal mechanisms becomes greater; relationships based on traditional old institutions are gradually replaced by new ones. There is a need to emphasize the dynamic of the process and to investigate changing patterns of business climate constraints' impacts on different groups of investors. Therefore, the investigation of variability of responses between foreign and local investors depending on the degree of transition from centrally-planned economy to the market one might be an important task.

Furthermore, learning and adapting in the foreign environment enhances the ability of a foreign firm to overcome LOF (Petersen and Pedersen, 2002). Lack of familiarity with the local environment might disappear by the time foreign firms collect information and adjust to local rules and norms of behavior. Forward-looking research can focus on comparisons of local firms and foreign companies depending on their age in operation in a particular market.

Large MNE sometimes miss certain investment opportunities in transition economies, where operational conditions are 
more challenging or the markets are small. More effort is required to encourage small- and medium-scale international investors to step into transition economies. In our study, the focus was upon differences between foreign and local investors, while the size of foreign companies was not taken into consideration. There is a possibility that small- and medium-sized foreign investors demonstrate different characteristics in their evaluations of business climate compared with large MNE. Besides, Nachum (2010) suggested that foreign companies enjoy superior advantages when compared with purely domestic local firms, but these differences disappear when affiliates are compared with local MNE. On the contrary, Jiang and Stening (2013) failed to support the hypothesis that the multi-nationality of local firms impacts their firm performance compared to foreign competitors. In our study, we did not pay attention to whether local companies have international experience or not. Future researchers are advised to fill this gap.

Forward looking research can also investigate the differences between foreign and local investors separately for major cities and smaller towns. Geographical closeness of foreign investors to a specific transition country might also have an impact on their LoF, as a firm that expands abroad close to its home region might experience less LoF compared to a move further away from a familiar geographical pattern (Kudina, 2012; Golubeva, 2016).

We also encourage further research, which addresses different sectors of the economy. A study measuring the perceptions of business owners covering different sectors may prove important in providing policy decision-makers with more precise recommendations about the needs of foreign and local investors existing in different branches.

\section{Conclusions}

From an institutional perspective, transition economies are characterized by ambiguities where the newly-formed institutions conflict with former central planning structures. This complexity could be a critical challenge for most outsiders operating in transition economies, and could be a competitive advantage for local firms that are deeply rooted in this environment. The findings of this study, however, reveal that both local and foreign firms have their competitive advantages as well as competitive disadvantages, at least as perceived by managers of these companies. LoF and LoL appear as a balanced outcome of firm-specific advantages, possessed by foreign investors, and location and institutional advantages, utilized by the local companies.

Governments of transition economies can benefit from the conclusions of our study, especially if they would like to improve their business climates through the enhancement of fair competition between local and foreign investors. The empirical evidence of our study suggests that there is a need to assist foreign investors in mitigating disturbances related to the institutional aspects of business climate. By way of contrast, providing incentives and necessary support for local firms should be connected to the development of FSA.

When constraints of the business climate have the same influence on foreign and local investors then the development of similar incentivizing policies by host governments are justified for all types of investors. The identifiable differences in perceptions of business climate variables by foreign and local investors, on the contrary, are perhaps the most problematical challenges for sound policy development. In the name of improving the region's reputation for foreign business friendliness, countries and regions may commit significant public resources in ways that partially neglect the interests of the domestic sectors or their economies as a whole.

In order to reduce the risk of any negative impact on reforming business climate, it is wise to consider possible competing interests when examining policy implications. For instance, regulations prohibiting tax-avoidance policies of MNEs may impact negatively the profits of foreign firms yet simultaneously establish 'fair rules of the game' for local investors and society in general. The role of the government during the institutional transition is exceptionally important, among others, due to the contradictory task of enabling both foreign- and locally-owned firms to capture business opportunities.

Generalization is the antithesis of this study's objective to analyze region-specific, individual firms' perceptions of the business climate. Making progress in measuring the perception of different variables of business climate is an important contribution towards identifying specific areas for reforms in public policy. A significant research agenda still lies ahead with continuing efforts for collecting both perception and objective data on a firm-level basis, and to compare these two data sources in order to better capture patterns that may emerge.

This study adds to the knowledge of factors that can be perceived differently by local and foreign investors in transition economies, which is important for policy-makers and development agencies to promote foreign (and local) investments. Drawing on institutional theory and the concept of LoF in their application to transition economies, the study attempts to expand the research domain in the context of business climate variables faced by foreign firms operating in transition economies. 


\section{Acknowledgments}

The author is grateful for helpful comments from Editor and two anonymous referees. Proofreading assistance of Dr. Alan Wood (UK) is acknowledged.

\section{References}

Al Nasser, O. A. (2010). How Does Foreign Direct Investment Affect Economic Growth? The Role of Local Conditions. Latin American Business Review, 11, 111-139. https://doi.org/10.1080/10978526.2010.486715

Athukorala, P. (2009). Trends and Patterns of Foreign Direct Investments in Asia: A Comparative Perspective. The Journal of Applied Economic Research, 3(4), 365-408. https://doi.org/10.1177/097380100900300403

Bayraktar, N. (2013). Foreign Direct Investment and Investment Climate. Procedia Economics and Finance, 5, 83-92. https://doi.org/10.1016/S2212-5671(13)00013-0

Bertrand, M., \& Mullainathan, S. (2001). Do People Mean What They Say? Implications for Subjective Survey Data. The American Economic Review, 91(2), 67-72. https://doi.org/10.1257/aer.91.2.67

Bevan, A.; Estrin, S., \& Meyer, K. (2004). Foreign Investment Location and Institutional Development in Transition Economies. International Business Review, 13, 43-64. https://doi.org/10.1016/j.ibusrev.2003.05.005

Birsan, M., \& Buiga, A. (2009). FDI Determinants: Case of Romania. Transition Studies Review, 15, 726-736. https://doi.org/10.1007/s11300-008-0033-2

Blonigen, B. A., \& Piger, J. (2011). Determinants of Foreign Direct Investments. Working Paper no. 16704, National Bureau of Economic Research. https://doi.org/10.3386/w16704

Contractor, F. J., Kundu, S. K., \& Hsu, C. C (2003). A Three-stage Theory of International Expansion: the Link Between Multinationality and Performance in the Service Sector. Journal of International Business Studies, 34(1), 5-18. https://doi.org/10.1057/palgrave.jibs. 8400003

Cuervo-Cazurra, A., Maloney, M. M., \& Manrakhan, S. (2007). Causes of the Difficulties in Internationalization. Journal of International Business Studies, 38(5), 709- 725. https://doi.org/10.1057/palgrave.jibs.8400295

Deichmann, J., Karidis, S., \& Sayek, S. (2003). Foreign Direct Investment in Turkey: Regional determinants. Applied Economics, 35(16), 1767-1778. https://doi.org/10.1080/0003684032000126780

Devonshire-Ellis, C., \& Zhang, S. (2011). Analyzing Chinese financial reporting. China Briefing: Magazine and Daily News Service. February, 7.

Dierks, A., Kuklinski, C. P. J. W., \& Moser, R. (2013). How Institutional Change Reconfigures Successful Value Chains: The Case of Western Pharma Corporations in China. Thunderbird International Business Review, 56(5), 393-406. https://doi.org/10.1002/tie.21533

Djankov, S.; Ganser, T, McLeish, C., Ramalho, R., \& Shleifer, A. (2009). The Effect of Corporate Taxes on Investment and Entrepreneurship. Mimeo, World Bank. https://doi.org/10.2139/ssrn.1091238

Dollar, D., Hallward-Driemeier, M., \& Mengistae, T. (2005). Investment Climate and Firm Performance in Developing Economies. Economic Development and Cultural Change, 54(1), 1-31. https://doi.org/10.1086/431262

Donor Committee for Enterprise Development. (2008). "Supporting Business Environment Reforms. Practical Guidance for Development Agencies". Retrieved from http://rru.worldbank.org/documents/DonorGuidance.pdf Accessed on May 302011.

Dunning, J. H., \& Lundan, S. M. (2008). Institutions and the OLI paradigm of the multinational enterprise". Asia Pacific Journal of Management, 25(4), 573-593. https://doi.org/10.1007/s10490-007-9074-z

Durlauf, S. N., Kourtellos, A., \& Tan, C. M. (2008). Are Any Growth Theories Robust? The Economic Journal 118(527), 329-346. https://doi.org/10.1111/j.1468-0297.2007.02123.x

Eden, L., \& Miller, S. R. (2001). Opening the Black Box: The Multinational Enterprise and the Cost of Doing Business Abroad. In D.H. Nagao (Ed.), Best Paper Proceedings, Academy of Management Meeting. Washington DC, IM C1-C6.

Elango, B. (2009). Minimizing Effects of 'Liability of Foreignness': Response Strategies of Foreign Firms in the United States. Journal of World Business, 44, 51-62. https://doi.org/10.1016/j.jwb.2008.03.012

Estrin, S., Baghdasaryan, D., \& Meyer, K. E. (2009). The Impact of Institutional and Human Resource Distance on International Entry Strategies. Journal of Management Studies, 46(7), 1171-1196. https://doi.org/10.1111/j.1467-6486.2009.00838.x 
Freckleton, M., Wright, A., \& Craigwell, R. (2012). Economic Growth, Foreign Direct Investment and Corruption in Developed and Developing Countries. Journal of Economic Studies, 39(6), 639-652. https://doi.org/10.1108/01443581211274593

Gelb, A., Ramachandran, V., Kedia Shah, M., \& Turner, G. (2007). What Matters To African Firms? The Relevance of Perceptions Data. Policy Research Working Paper no. 4446, The World Bank, Washington DC.

Glaeser, E., La Porta, R., Lopez-de-Silanes, F., \& Shleifer, A. (2004). Do Institutions Cause Growth? Journal of Economic Growth, 9, 271-303. https://doi.org/10.1023/B:JOEG.0000038933.16398.ed

Golubeva, O. (2001). Foreign investment decision-making in transition economies, PhD. Thesis, Stockholm: School of Business, Stockholm University.

Golubeva, O. (2015). Business Climate in Russia: Swedish Investors' Perspective. Baltic Worlds 3-4, 76-86.

Golubeva, O. (2016). Determinants of Swedish Foreign Direct Investments (FDI): How Important is Profitability? Economics and Finance Review, 4(10), 1-19. Available at http://www.businessjournalz.org/articlepdf/EFR-41001-June-2016-4(10)-a.pdf

Goswami, G.G. \& Haider, S. (2014). Does Political Risk Deter FDI Inflow? Journal of Economic Studies, 41(2), 233-252. https://doi.org/10.1108/JES-03-2012-0041

Hallward-Driemeier, M., \& Aterido, R. (2009). Comparing Apples with....Apples: how to Make (more) Sense of Subjective Rankings of Constraints to Business. Policy Research Working Paper Series no. 5054, The World Bank.

Hallward-Driemeier, M., \& Pritchett, L. (2011). How Business Is Done and the 'Doing Business' Indicator. The Investment Climate When Firms Have Climate Control. Policy Research Working Paper no. 5563, The World Bank, Financial and Private Sector Development, Office of the Chief Economist, February 2011.

Hao, L., Gao, C., \& Liu, Z. (2007). Customer-based Brand Equity and Improvement Strategy for Mobile Phone Brands: Foreign Versus Local in the Chinese Market. International Management Review, 3(3), 76-84.

Hermelo, F. D., \& Vassolo, R. (2010). Institutional Development and Hypercompetition in Emerging Economies. Strategic Management Journal, 31(13), 1457-1473. https://doi.org/10.1002/smj.898

Hillman, A. J., Keim, G. D., \& Schuler, D. (2004). Corporate Political Activity: A Review and Research Agenda, Journal of Management, 30, 837-857. https://doi.org/10.1016/j.jm.2004.06.003

Hornberger, K., Battat, J., \& Kusek, P. (2011). Attracting FDI: How Much Does Investment Climate Matter? Working Paper no. 327, The World Bank, Financial and Private Sector Development, August 2011.

Huang, Y. (2008). Capitalism with Chinese Characteristics: Entrepreneurship and the State. New York: Cambridge University Press. https://doi.org/10.1017/CBO9780511754210

Hymer, S. (1960/1976). The International Operations of National Firms: A Study of Direct Foreign Investment. Cambridge, MA: MIT Press.

Insch, G. S., \& Miller, S. R. (2005). Perception of Foreignness: Benefit or Liability? Journal of Managerial Issues, 17(4), 423-438.

Jiang, F., \& Stening, B. W. (2013). Do Indigenous Firms Incur a Liability of Localness When Operating in Their Home Market? The Case of China. Journal of World Business, 48, 478-489. https://doi.org/10.1016/j.jwb.2012.09.004

Johanson, J., \& Vahlne, J. E. (2009). The Uppsala Internationalization Process Model Revisited: From Liability of Foreignness to Liability of Outsidership. Journal of International Business Studies, 40, 1411-1431. https://doi.org/10.1057/jibs.2009.24

Keola, S. (2008). Investment Climates in CLMV (Cambodia, Laos, Myanmar, Vietnam): their Global Positions. In Development Strategy for CLMV in the Age of Economic Integration, ed. C. Sotharith, pp. 141-168. ERIA Research Project Report 2007-4, Chiba: IDE-JETRO.

Kinda, T. (2010). Investment Climate and FDI in Developing Countries: Firm-Level Evidence. World Development, 38(4), 498-513. https://doi.org/10.1016/j.worlddev.2009.12.001

Kogut, B., \& Zander, U. (2000). Did Socialism Fail to Innovate? A Natural Experiment of the Two Zeiss Companies. American Sociological Review, 65(2), 169-190. https://doi.org/10.2307/2657436

Kronborg, D., \& Thomsen, S. (2009). Foreign Ownership and Long-term Survival. Strategic Management Journal, 30(2), 207-219. https://doi.org/10.1002/smj.732

Kudina, A. (2012). Regional Strategies, Liability of Foreignness, and Firm Performance. Multinational Business Review, 
20(4), 331-351. https://doi.org/10.1108/15253831211286255

La Porta, R., \& Shleifer, A. (2008). The Unofficial Economy and Economic Development. Brookings Papers on Economic Activity, 275-352. https://doi.org/10.3386/w14520

Laeven, L., \& Woodruff, C. (2008). The Quality of the Legal System, Firm Ownership, and Firm Size. Working paper, IMF, Washington, DC. https://doi.org/10.1086/649031

Long, C. (2010). Does the Rights Hypothesis Apply to China. Journal of Law and Economics, 53(4), 629-650.

Lu, J. W., \& Beamish, P. W. (2004). International Diversification and Firm Performance: the S-curve Hypothesis". Academy of Management Journal, 47(4), 598-609. https://doi.org/10.2307/20159604

Makhija M. (2003). Comparing the Resource-based and Market-based Views of the Firm: Empirical Evidence from Czech Privatization. Strategic Management Journal, 24(5), 433-451. https://doi.org/10.1002/smj.304

Meyer, K. E., Estrin, S. S. K., Bhaumik, S. K., \& Peng, M. W. (2009). Institutions, Resources, and Entry Strategies in Emerging Economies. Strategic Management Journal, 30(1), 61-80. https://doi.org/10.1002/smj.720

Miller, S. R. \& Eden, L. (2006). Local Density and Foreign Subsidiary Performance. Academy of Management Journal, 49, 341-356. https://doi.org/10.5465/AMJ.2006.20786081

Morris, R., \& Aziz, A. (2011). Ease of Doing Business and FDI Inflow to Sub-Sharan Africa and Asian Countries. Cross Cultural Management: An international Journal, $18(4), \quad 400-411$. https://doi.org/10.1108/13527601111179483

Motoyama, Y., \& Hui, I. (2015). How Do Business Owners Perceive the State Business Climate? Using Hierarchical Models to Examine the Business Climate Perceptions, State Rankings, and Tax Rates. Economic Development Quarterly, 29(3), 262-274. https://doi.org/10.1177/0891242415589025

Mottaleb, K. A., \& Kalirajan, K. (2010). Determinants of Foreign Direct Investment in Developing Countries: A Comparative Analysis. The Journal of Applied Economic Research, 4(4), 369-404. https://doi.org/10.1177/097380101000400401

Nachum, L. (2010). When Is Foreignness an Asset or a Liability? Explaining the Performance Differential Between Foreign and Local Firms. Journal of Management, 36(3), 714-739. https://doi.org/10.1177/0149206309338522

Navaretti, G. B., \& Venables, A. J. (2004). Multinational Firms in the World Economy. Princeton, NJ: Princeton University Press.

Nnadozie, E., \& Njuguna, A. (2011). Investment Climate and Foreign Direct Investment in Africa. Working Paper, 6th African Economic Conference, Ethiopia, October 26-28, 2011.

North, D. (1990). Institutions, Institutional Change and Economic Performance. New York: Cambridge University Press. https://doi.org/10.1017/CBO9780511808678

Obradovića, S., Fedajevb, A., \& Nikolićb, D. (2012). Analysis of Business Environment Using the Multi-Criteria Approach - Case of Balkan's Transition Economies. Serbian Journal of Management, 7(1), 37-52. https://doi.org/10.5937/sjm1201037O

OECD. (2015). FDI in Figures. FDI Continues to Rise in the First Half of 2015 OECD. October, 2015.

Oliver, C., \& Holzinger, I. (2008). The Effectiveness of Strategic Political Management: A Dynamic Capabilities Framework, Academy of Management Review, 33, 496-520. https://doi.org/10.5465/AMR.2008.31193538

Osland, A., \& Osland, J. S. (2005). Contextualization and Strategic International Human Resource Management Approaches: The Case of Central America and Panama. International Journal of Human Resource Management, 16(12), 2218-2236. https://doi.org/10.1080/09585190500358653

Peng, M. W. (2003). Institutional Transitions and Strategic Choices, Academy of Management Review 28, $275-296$.

Perez-Batres, L. A., \& Eden, L. (2008). Is There a Liability of Localness? How Emerging Market Firms Respond to Regulatory Punctuations. Journal of International Management, 14(3), 232-251. https://doi.org/10.1016/j.intman.2007.10.004

Petersen, B., \& Pedersen, T. (2002). Coping with Liability of Foreignness: Different Learning Engagements of Entrant Firms. Journal of International Management, 8(3), 339-350. https://doi.org/10.1016/S1075-4253(02)00068-6

Phillips, L. M. (2006). Growth and the Investment Climate: Progress and Challenges for Asian Economies. Working Paper, March 2006, Institute of Development Studies. https://doi.org/10.1111/j.1759-5436.2006.tb00269.x

Quazi, R. M., \& Tandon, S. (2011). Foreign Direct Investment and Investment Climate in China and India: a 
Comparative Analysis, Working paper, January 2011.

Reinhart, C. \& Rogoff, K. (2009). The Aftermath of Financial Crises. American Economic Review 99(2), 466-472. https://doi.org/10.1257/aer.99.2.466

Sekkat, K., \& Veganzones-Varoudakis, M. A. (2007). Openness, Investment Climate, and FDI in Developing Countries. Review of Development Economics, 11(4), 607-620. https://doi.org/10.1111/j.1467-9361.2007.00426.x

Sethi, D., \& Guisinger, S. (2002). Liability of Foreignness to Competitive Advantage: How Multinational Enterprises Cope with the International Business Environment. Journal of International Management, 8(3), 223-240. https://doi.org/10.1016/S1075-4253(02)00067-4

Shinkle, G. A., \& Kriauciunas, A. P. (2012). The Impact of Current and Founding Institutions on Strength of Competitive Aspirations in Transition Economies. Strategic Management Journal, 33, 448-458. https://doi.org/10.1002/smj.1946

Shostya, A. (2014). The Effect of the Global Financial Crisis on Transition Economies. Atlantic Economic Journal, 42, 317-332. https://doi.org/10.1007/s11293-014-9418-2

Tan, D. \& Meyer, K.E. (2011). Country-of-origin and Industry FDI Agglomeration of Foreign Investors in an Emerging Economy. Journal of International Business Studies, 42, 504-520. https://doi.org/10.1057/jibs.2011.4

UNCTAD. (2014). FDI into and out of Transition Economies Reached Record Levels in 2013. Geneva, Switzerland, June 23, 2014.

UNCTAD. (2015a). World Investment Report 2015. Reforming International Investment Governance. United Nations publications, Geneva.

UNCTAD. (2015b). Handbook of Statistics 2015. United Nations Publications, New York, USA.

Walsh, I., Bhatt, J. M., \& Bartunek, J. M. (2009). Organizational Knowledge Creation in the Chinese Context, Management and Organization Review, 5, 261-278. https://doi.org/10.1111/j.1740-8784.2008.00121.x

Wei, T. \& Clegg, J. (2014). Liability of Foreignness in Internationalization in Emerging Economies: Lessons from Acquiring a Chinese Firm. Published online in Wiley Online Library. Wiley Periodicals. Inc, 103-117.

Williams, N. L., Ridgman, T., Shi, Y., \& Ferdinand, N. (2014). Internationalization as Interaction: A Process Perspective on Internationalization From a Small Developing Country. Thunderbird International Business Review, 56(2), 127-144. https://doi.org/10.1002/tie.21607

Xu, D., Zhou, C., \& Phan, P. H. (2010). A Real Options Perspective on Sequential Acquisitions in China. Journal of International Business Studies, 41(1), 166-174. https://doi.org/10.1057/jibs.2009.16

Xu, L.C. (2010). The Effects of Business Environments on Development Surveying. New Firm-Level Evidence. Policy Research Working Paper no. 5402. The World Bank Development Research. Group Finance and Private Sector Development, August 2010.

Yildiz, H. E., \& Fey, C. F. (2012). The Liability of Foreignness Reconsidered: New Insights From the Alternative Research Context of Transforming Economies. International Business Review, 21, 269-280. https://doi.org/10.1016/j.ibusrev.2011.03.002

Yip, G. A. (2003). Total Global Strategy II. Prentice Hall, Englewood Cliffs, NJ.

Yiu, D. W., Hoskisson, R. E., Bruton, G. D., \& Li, Y. (2014). Dueling Institutional Logics and the Effect on Strategic Entrepreneurship in Chinese Business Groups, Strategic Entrepreneurship Journal, 8, 195-213. https://doi.org/10.1002/sej.1177

Zaheer, S. (1995). Overcoming the Liability of Foreignness. Academy of Management Journal, 38(2), 341-363. https://doi.org/10.2307/256683

Zhou, K. Z., Tse, D. K., \& Li, J. J. (2006). Organizational Changes in Emerging Economies: Drivers and Consequences. Journal of International Business Studies, 37, 248-263. https://doi.org/10.1057/palgrave.jibs.8400186

\section{Notes}

Note 1. Access to BEEPS data can be granted for research purposes by the World Bank and EBRD after official registration and acceptance of confidentiality undertakings. See http://data.worldbank.org/data-catalog/BEEPS_and http://ebrd-beeps.com/

Note 2. Mann-Whitney U test (also sometimes called the Mann-Whitney-Wilcoxon), is a nonparametric test of the null 
hypothesis, which does not require a normal distribution of the data. The test determines whether there is a statistically significant difference in scores for two variables measured at the ordinal level. Since the idea of a 'mean' makes little sense for ordinal data, the Mann Whitney procedure in SPSS is to take scores for the two groups and put them into one column, then rank order them from lowest to highest. Once the ranks are assigned, the scores are split back into the two groups. Then the mean of the 'ranks' in each group is computed, and the test is completed to see whether there is a statistically significant difference in the mean ranks for each group. 'Mean Rank' is the mean rank score for each group.

\section{Appendix A. Selected research on determinants of FDI and business climate}

\begin{tabular}{|c|c|}
\hline $\begin{array}{l}\text { Researcher(s), year of } \\
\text { publication }\end{array}$ & Topic studied \\
\hline Al Nasser (2010) & $\begin{array}{l}\text { Impact of local conditions on FDI } \\
\text { and economic growth }\end{array}$ \\
\hline Bayraktar (2013) & $\begin{array}{l}\text { Link between FDI and investment } \\
\text { climate by using weighted indices }\end{array}$ \\
\hline Bevan et al. (2004) & $\begin{array}{l}\text { FDI in East European transition } \\
\text { economies and institutional } \\
\text { framework }\end{array}$ \\
\hline Deichmann et al. (2003) & $\begin{array}{l}\text { A study of } 293 \text { foreign firms } \\
\text { locating in Turkey }\end{array}$ \\
\hline Dollar et al. (2005) & $\begin{array}{l}\text { Relationships between investment } \\
\text { climate and performance } \\
\text { outcomes }\end{array}$ \\
\hline Freckleton et al. (2012) & $\begin{array}{l}\text { Impact of corruption on FDI and } \\
\text { economic growth }\end{array}$ \\
\hline Golubeva (2016) & $\begin{array}{l}\text { Main determinants have been } \\
\text { tested on Swedish FDI portfolio }\end{array}$ \\
\hline
\end{tabular}

Keola (2008)

Role of the investment climate in attractiveness for foreign capital

Kinda (2010) Investment climate and FDI across 77 developing countries

La Porta and Shleifer Main obstacles to a better (2008) investment climate in CIS countries

Mottaleb and Kalirajan The effect of business (2010) environment on FDI in 68 developing countries

Morris and Aziz (2011) Relationship between business climate and the inflow of FDI

Navaretti and Venables Determinants of FDI into (2004) developing countries during $1990 \mathrm{~s}$

Main conclusions

Inflation, trade, school attainment, and telephone lines are the most significant determinants of FDI.

Countries with better records of World Bank's "Ease of Doing Business" indices tend to attract more FDI.

Quality of formal institutions and informal institutions (for Russia) are important for attracting FDI.

Financial development encourages FDI, and infrastructure development increases the probability of MNE location.

Weak institutions affect the business environment; power outages and customs delays are the most serious bottlenecks.

Corruption has a negative impact on economic growth through its indirect effect on FDI.

Profitability of investments appeared to be a key determinant of Swedish FDI followed by GDP and a joint border dummy variable; economic freedom is also significant.

Emphasis the importance of supply/demand factors such as population sizes and natural resources.

Constraints related to finance, availability of infrastructure and good institutions hamper FDI.

Main obstacles: taxation, corruption, poor governance, weak legal and regulatory frameworks, need for structural reforms.

Regulatory frameworks, bureaucratic hurdles and red tape, judicial transparency and corruption in the host country influence the inflow of FDI.

Two indicators - registering property and trading across borders - are related to FDI inflows.

Openness, including trade and exchange market reforms, physical infrastructure and political and economic risks are important.

Nnadozie and Njuguna The relationship between (2011) investment climate and FDI in Africa.

Phillips (2006)

Role of the investment climate for attractiveness for foreign capital

Quazi and Tandon (2011) Comparison of China and India as locational advantage of FDI

Sekkat

and The importance of investment Veganzones-Varoudakis climate in attracting FDI

Business rules and regulations, economic, policy, governance and political risks are important when attracting FDI into Africa.

Economic and political stability, rule of law, adequate infrastructure, labor policies, and access to finance are important.

China fares better against India in terms of infrastructure, financial market, monetary system, corruption, and trade regime.

Infrastructure, sound economic and political conditions, trade openness and liberalization are important. 
Appendix B. Selected macroeconomic indicators and indexes for 30 transition economies.

\begin{tabular}{|c|c|c|c|c|c|}
\hline Country & $\begin{array}{l}\text { GDP per } \\
\text { capita } \\
2015 \\
\text { (current } \\
\text { US\$) (1) }\end{array}$ & $\begin{array}{l}\text { GDP growth } \\
\text { (annual \%) } \\
2015(2)\end{array}$ & $\begin{array}{l}\text { Transition } \\
\text { rating by EBRD } \\
(2014)(3)\end{array}$ & $\begin{array}{lr}\text { Ease of } & \text { Doing } \\
\text { Business } & \text { Rank } \\
\text { (June 2015) } & (4)\end{array}$ & $\begin{array}{l}\text { Sovereign credit } \\
\text { rating by Standard } \\
\& \text { Poor's }(5)\end{array}$ \\
\hline Albania & 3965 & 2.6 & 3.498 & 97 & $\mathrm{~B}+$ \\
\hline Armenia & 3500 & 3.0 & 3.443 & 35 & B1 (Moody’s) \\
\hline Azerbaijan & 5496 & 1.1 & 2.890 & 63 & $\mathrm{BB}+$ \\
\hline Belarus & 5740 & -3.9 & 2.167 & 44 & B- \\
\hline Bosnia and Herzegovina & 4198 & 3.2 & 3.055 & 79 & B \\
\hline Bulgaria & 6820 & 3.0 & 3.722 & 38 & $\mathrm{BB}+$ \\
\hline Croatia & 11536 & 1.6 & 3.832 & 40 & BB \\
\hline Czech Republic & 17231 & 4.2 & n.a. & 36 & AA- \\
\hline Estonia & 17295 & 1.1 & n.a. & 16 & AA- \\
\hline Former $\quad$ Yugoslav & 4853 & 3.7 & 3.555 & 12 & BB- \\
\hline \multicolumn{6}{|l|}{ Republic of Macedonia } \\
\hline Georgia & 3796 & 2.8 & 3.498 & 24 & BB- \\
\hline Hungary & 12259 & 2.9 & 3.888 & 42 & $\mathrm{BB}+$ \\
\hline Kazakhstan & 10508 & 1.2 & 3.057 & 41 & BBB- \\
\hline Kosovo & 3553 & 3.6 & 2.888 & 66 & n.a. \\
\hline Kyrgyz Republic & 1103 & 3.5 & 3.388 & 67 & B \\
\hline Latvia & 13665 & 1.9 & 3.943 & 22 & A- \\
\hline Lithuania & 14172 & 1,6 & 3.943 & 20 & A- \\
\hline Moldova & 1843 & -0.5 & 3.277 & 52 & B3 (Moody’s) \\
\hline Mongolia & 3973 & 2.3 & n.a. & 56 & B- \\
\hline Montenegro & 6415 & 3.4 & 3.332 & 46 & $\mathrm{~B}+$ \\
\hline Poland & 12494 & 3.6 & 4.000 & 25 & $\mathrm{BBB}+$ \\
\hline Romania & 8973 & 3.7 & 3.667 & 37 & BBB- \\
\hline Russia & 9057 & -3.7 & 3.278 & 51 & $\mathrm{BB}+$ \\
\hline Serbia & 5144 & 0.7 & 3.167 & 59 & BB- \\
\hline Slovak Republic & 15963 & 3.6 & 3.943 & 29 & $\mathrm{~A}+$ \\
\hline Slovenia & 20713 & 2.9 & 3.555 & 29 & A \\
\hline Tajikistan & 926 & 4.2 & 2.950 & 132 & n.a. \\
\hline Turkey & 9130 & 4.0 & n.a. & 55 & $\mathrm{BB}$ \\
\hline Ukraine & 2115 & -9.9 & 3.277 & 83 & B- \\
\hline Uzbekistan & 2132 & 8.0 & 2.280 & 87 & n.a. \\
\hline
\end{tabular}

Notes: (1) Data source of GDP per capita, current US\$: http://data.worldbank.org/indicator/NY.GDP.PCAP.CD

(2) Data source of GDP growth, annual \%: http://data.worldbank.org/indicator/NY.GDP.MKTP.KD.ZG

(3) Transition rating by EBRD, where a lower scale represents little or no change from a rigid centrally-planned economy and a higher figure represents the standards of an industrialized market economy. Data source: http://www.ebrd.com/what-we-do/economic-research-and-data/data.html

(4) The Doing Business project provides objective measures of business regulations and their enforcement across economies on their ease of doing business, from 1 (more conducive environment for business) to 189 (less favorable). Data source: http://www.doingbusiness.org/

(5) Countries credit rating by Standard \& Poor's was retrieved through http://www.tradingeconomics.com/country-list/rating. For Standard \& Poor's, a credit rating of BBB- or higher is considered to be investment grade. Ratings $\mathrm{BB}+$ and below are considered to be speculative grades. When Standard \& Poor's rating is not available, the appropriate rating by Moody's is provided.

\section{Copyrights}

Copyright for this article is retained by the author(s), with first publication rights granted to the journal.

This is an open-access article distributed under the terms and conditions of the Creative Commons Attribution license which permits unrestricted use, distribution, and reproduction in any medium, provided the original work is properly cited. 